\title{
Quantitative Assessment of Hab Watershed Using Geoinformatics
}

\author{
Rakhshanda Sadaf ${ }^{1}$, Abel Ramoelo², Rana Zain Nabi khan³, Isma Younes ${ }^{4}$ \& Haris Zafar ${ }^{5}$ \\ ${ }^{1}$ Department of Geology, Federal Urdu University of Science and Technology, Karachi, Pakistan \\ ${ }^{2}$ Scientific Services, South African National Parks, Pretoria, South Africa \& University of Limpopo, Sovenga, \\ South Africa \\ ${ }^{3}$ Centre of Excellence in water Resources Engineering UET Lahore, Pakistan \\ ${ }^{4}$ Department of Geography, University of the Punjab, Pakistan \\ ${ }^{5}$ GIS Engineer, Cyber internet services PVT ltd, Pakistan \\ Correspondence: Rakhshanda Sadaf, Department of Geology, Federal Urdu University of Science and \\ Technology, Karachi, Pakistan. Tel: 92-333-025-2794. E-mail: r.sadaf@fuuast.edu.pk
}

Received: October 9, 2019 Accepted: November 5, 2019 Online Published: November 15, 2019

\begin{abstract}
Morphometric assessment of the watersheds is considered highly critical to appraise its hydrological characteristics, such as, general geology, structure, geomorphology and climate conditions. In this study, morphometric analysis of Hab Watershed has been carried out through Geospatial Technology (RS \& GIS) in a systematic manner to examine its Geo-hydrological characteristics. The drainage network of Hab is typically dendritic and semi-dendritic indicating its heterogeneous lithology. Recent study reveals increase in stream order, substantially decreases the stream total length. drainage density of the Hab Watershed indicates the characteristics of its typical soil. Drainage texture value for Hab watershed is 0.18 . Low drainage density value reveals that the region has a permeable and porous subsurface material with low relief. The shape of the basin has been observed as quite elongated. The findings of this study reveal that GIS based morphometric analysis is highly effective tool for geo-hydrological study of watersheds.
\end{abstract}

Keywords: morphometric analysis, geospatial technologies, quantitative analysis, drainage density

\section{Introduction}

\subsection{Problem Statement}

The availability of water is the main factor for human habitation, survival and social and economic growth on earth. It is an essential requirement for all the living organisms of the planet of the earth. Therefore, there is need for sustainable usage of water. Non-availability of freshwater resources is posing a serious threat to the world and especially it is challenging for third world countries. About $70 \%$ of earth's portion is covered by water whereas its only $3 \%$ is fresh water but very little amount of this freshwater is available for the consumption of human-beings (Lefort, 1996). However, only $0.01 \%$ quantity of world's entire amount is accessible for human consumption located rivers and wetlands (Hinrichsen, 1998).

Pakistan water resources are diminishing rapidly mainly owing to negligence, deficiencies of management sector and national and international politics on water sector. Present per capita availability of water is about 1000 cubic meters which is very low, is further gradually declining taking Pakistan in to the most critical zone (Islam, 2012). Situation of water scarcity is more severe especially in cities where rate of industrialization and urbanization is high especially in the megacity Karachi and its surrounding areas. development of Hab industrial estate on the western margin of Karachi city is ultimately demanding more which is causing water shortage problems in region (Sadaf, 2014).

Hab River is the most important resource of water for Hab estate and to some extent for Karachi City (about 100 Million Gallons / Day). It is therefore considered one of the most important source to investigate systematically for the recent and future requirements of the region. According to past studies Hab watershed is a macro watershed (Sadaf, 2014 and Sadaf, et al, 2017). Hab Dam was constructed in June 1981 to store and properly manage water supply to surrounding areas of region and for effective flood control. There is a need to properly assess and monitor changes in dam levels.

Geoinformatics is a powerful and alternative source for monitoring water resources and hence pertinent to water 
resources management. Hydrological analysis has become more effective with the integration of geospatial techniques. Topographic analysis has also become a convenient task with the involvement of GIS.

\subsection{Objectives of the Study}

The objectives of the study is to undertake quantitative assessment of Hab Watershed using Geoinformatics. The specific objective are to

- Establish the relationship between morphometric characteristics and hydrological characteristics.

- Develop the correlations between the different morphometric parameters and geological structures

- Evaluate the morphometric characteristics by performing quantitative analysis in GIS envoirment.

- Examine the Hydrological characteristics of Hab River for sustainable water supply.

\subsection{Relevant Scholarship}

In all dimensions of hydrological sciences Geographic information system has provided the chance to appraise the catchment or basin geometry, its area, volume, channel network, drainage classification and divides, and extraction of its landscape properties like aspect and slope (Jha, 2017), Jenson, and Domingue (1988), Moore (1991). Conventional techniques are laborious and labour intensive (Martz and Garbrecht,1992). However, through GIS, very accurate and reproducible measurements are possible with the application of automated techniques on topographic maps (Richards, 1981).

Morphometric analysis of a watershed can easily be performed with the help of Geoinformatics (Tribe,1991; Shakil, 2012; Sangita and Nagarajan, 2012, Vandana, 2013, Magesh et al, 2013, Balakrishna, 2008).

Quantitative investigation of drainage area is a significant characteristic for categorization of a watershed (Aravinda \& Balakrishna, 2013). Assessment of linear and areal characteristics of a drainage basin are main factors in this regard (Strahler, 1964). Morphometric analysis provides the mathematical analysis and examination of the earth's surface (Nautiyal,1994). This analysis is a very important scientific tool for the fast and detailed information of the watersheds (Clarke,1996, Javed, 2009). Morphometric characteristics of a watershed provide detailed information about its configuration and development and all geomorphological and hydrological processes taking place in it (Korkalainen et al, 2007).

Digital Elevation Models (DEMs) are very useful and precise source of morphometric analysis of the watershed (Singh, 2013). Morphometric evaluation in Remote Sensing (RS) and GIS environment using DEM data (SRTM or ASTER) provides quick and precise technique for the evaluation of hydrological characteristics (El Bastawesy,2013, Farr and Kobrick, 2000). DEM data has already proved its significance for the extraction of various parameters of the watershed like slope, aspect, gradient, catchment divides, drainage network and upstream flow areas (Panhalkar, 2014, Mark, 1984, Tarboton, 1997, Grohmannetal, 2007).

\section{Material and Methodological Framework}

Present study is about Hab Watershed, which is situated in Baluchistan, Province and its geographical location is $25^{\circ}$ to $32^{\circ} \mathrm{N}$ and $61^{\circ}$ to $71^{\circ} \mathrm{E}$. It's about 55 percent area mountainous where alluvial and aeolian deposits are frequently found. Climatic conditions are arid, with low precipitation and high evaporation (WAPDA,1984).

Hab river is an important river of Baluchistan serving many parts in the province and also supplies water to Karachi, the largest city of Pakistan. The river is a part of Porali river system and its total drainage area is about 25,770 km2. Hab River emerges from the mountains near Khuzdar, $321.869 \mathrm{~km}$ North of Cape Monze and drains in Arabian sea (Figure 1). Its catchment area is long and narrow and it flows between the provincial boundary of Sindh and Baluchistan. Hab River is a perennial river which has intermittent flow and its flow direction is generally north to south. Catchment area of Hab watershed is $10036.204 \mathrm{~km} 2$ out of which $9064.9584 \mathrm{~km} 2$ is long and narrow mountainous (WAPDA, 1984). 


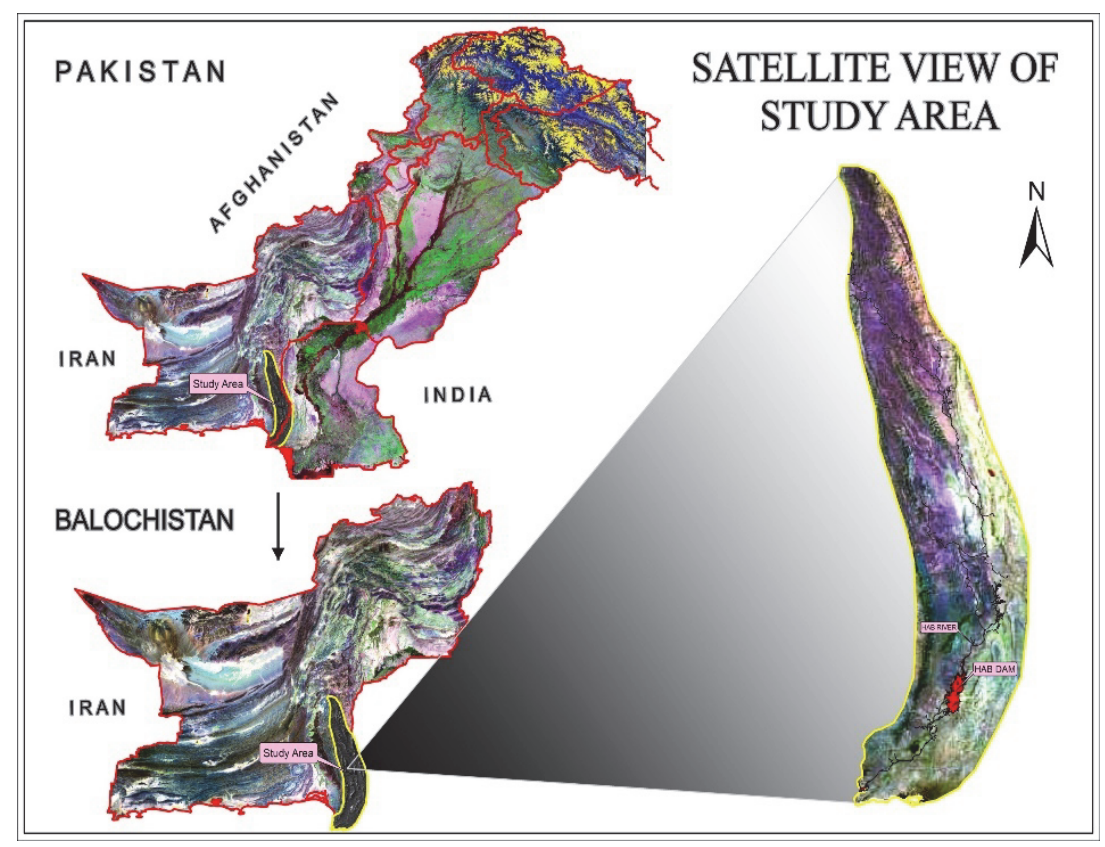

Figure 1. Location map of the study area

For the assessment of drainage network and potential of the watersheds, DEM data is quite useful. In this study SRTM (Shuttle Radar Topographic Mission of NASA) data of 30M resolution have been used (Figure 2)

The elevations of the coverage regions have been measured by using the SIR-C and X-SAR payload. This payload has flown two times onboard Space Shuttle Endeavour in 1994 to make acquisitions for generating a topographic map of eighty percent of global surface. (JPL, 2017).

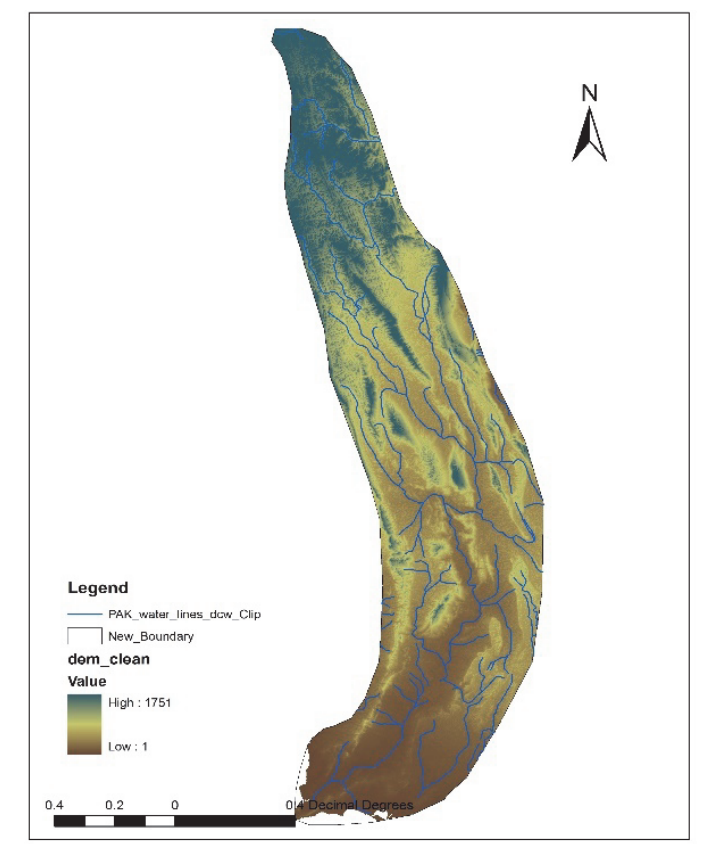

Figure 2. Digital elevation model (DEM) of study area

Many parameters have been calculated through morphometric analysis which provides the information about watershed's storage capacity, rocks character, and potential of watershed. Captioned study, through integrated use of 
satellite images, GIS techniques, digital elevation model (DEM) and topographic maps provides the various kinds of drainage parameters of Hab Watershed. Details of used data presented in Table no 1.

Table 1. Details of Data used in this study

\begin{tabular}{lll}
\hline Type of Data & Details of data used & Sources of data \\
\hline Toposheets & $35 \mathrm{~L} / 9,35 \mathrm{~K} / 16$ & survey of Pakistan \\
& $35 \mathrm{O} / 3,35 \mathrm{O} / 4,35 \mathrm{P} / 1$ & \\
SRTM global DEM & 3 -ARC $(90 \mathrm{~m}$ resolution),2000. & USGS website \\
Landsat 8 satellite & $152 / 42,152 / 43,153 / 41$, & https://landsat.usgs.gov \\
imagery & $153 / 42,153 / 43$ & \\
\hline
\end{tabular}

\subsection{Rectification and Geo-Referencing of Multispectral Satellite Images and Toposheets}

Toposheets and satellite images of study area have been geometrically georeferenced and rectified through utilization of WGS-84 datum and UTM projection. All Georeferenced topographic maps and images have been mosaiced by using Erdas Imagine software. Rectified Toposheets were used to delineate the watershed boundaries. DEM processing was performed using Arc GIS.

\subsection{DEM and Delineation of Watershed}

Study area has been defined by using topographical maps, satellite imageries and digital elevation model (DEM). DEM contains files of data about altitude of the ground of any specific region, generally at a permanent grid space over the "Bare Earth". It is downloaded in tiles and mosaiced by using ERDAS Imagine software (Figure 2). Delineation of the watershed boundaries, stream layers and different hydrological parameters have been calculated by using Arc Hydro tool in ArcGIS.

\subsection{Generation of Morphometric Map Using DEM}

DEM has been used to interpret the slope, topography, and hydrological characteristics map of the Hab watershed through spatial analysis in Arc GIS.

\subsection{Morphometric Analysis}

Morphometric investigation of study area has been carried out in GIS environment and different features which define the area were computed. The adopted methodologies (Pramanik, 2016) for the computation and assessment in present study are listed in Table 2.

Table 2. Methodological frame work for morphometric Analysis of Hab watershed

\begin{tabular}{llll}
\hline S. no. & Parameters & Formulae & References \\
\hline 1 & Relief ${ }^{\circledR}$ & $\mathrm{R}=\mathrm{H}-\mathrm{h}$ & $\begin{array}{l}\text { Hadley and Schumm } \\
(1961)\end{array}$ \\
2 & Relief ratio $(\mathrm{Rr})$ & $\mathrm{Rr}=\mathrm{R} / \mathrm{L}$ & Schumm (1963) \\
3 & Stream order $(\mathrm{So})$ & Hierarchical rank & Strahler (1964) \\
4 & Stream no & Order wise no of streams & Strahler (1964) \\
5 & Stream length $(\mathrm{Lu})$ & Length of the stream & Horton (1945) \\
6 & Meanstream length(Lsm) & Lsm=Lu/Nu & Strahler (1964) \\
7 & Bifurcation ratio $(\mathrm{Rb})$ & $(\mathrm{Rb})=\mathrm{Nu} / \mathrm{Nu}+1$ & Schumm $(1956)$ \\
8 & Mean bifurcation ratio $(\mathrm{Rbm})$ & $\mathrm{Rbm}=\mathrm{average}$ of bifurcation & Strahler (1957) \\
& & ratios of all order & \\
\hline $\mathbf{9}$ & Stream length ratio(RL) & $\mathrm{RL}=\mathrm{Lu} /(\mathrm{Lu}+1)$ & Horton (1945) \\
\hline
\end{tabular}




\begin{tabular}{llll}
$\mathbf{1 0}$ & Elongation ratio $(\mathrm{Re})$ & $\mathrm{Re}=\mathrm{D} / \mathrm{L}$ & Schumm (1956) \\
\hline $\mathbf{1 1}$ & Circularity ratio $(\mathrm{Rc})$ & $\mathrm{Rc}=4 \pi \mathrm{A} / \mathrm{P} 2$ & Strahler $(1964)$ \\
\hline $\mathbf{1 2}$ & Form factor $(\mathrm{Ff})$ & $\mathrm{Ff}=\mathrm{A} / \mathrm{L} 2$ & Horton $(1945)$ \\
\hline $\mathbf{1 3}$ & Drainage texture $(\mathrm{T})$ & $\mathrm{T}=\mathrm{Dd} * \mathrm{Fd}$ & Smith $(1950)$ \\
\hline $\mathbf{1 4}$ & Drainage frequency & $\mathrm{Fd}=\mathrm{Nu} / \mathrm{A}$ & Horton $(1945)$ \\
\hline $\mathbf{1 5}$ & Drainage density $(\mathrm{Dd})$ & $\mathrm{Dd}=\mathrm{Lu} / \mathrm{A}$ & Horton $(1945)$ \\
\hline
\end{tabular}

\section{Results and Discussion}

Geospatial technology (RS \& GIS) provided quite specific and accurate results through the morphometric analysis of watershed. This analysis provided the detailed quantitative evaluation of the watershed and also important information about the nature of rocks present there and about their hydrological characteristics. Hydrological characteristics of rocks have great importance for watershed management and morphometric assessment. They provide the precise knowledge about the drainage characteristics of rocks like its porosity and permeability, aspect and slope etc. Drainage characteristics of rocks found in basin, affect the flow of water, its distribution and infiltration capacity of a watershed. Arial and linear aspects for Hab watershed have been calculated. The details of these parameters are appended below:

\subsection{Linear Aspects}

All linear aspects of Hab watershed have been calculated from DEM through GIS. Details of the same is listed in Table 3.

Table 3. Linear Aspects of the Hab watershed

\begin{tabular}{lllllll}
\hline $\begin{array}{l}\text { Stream } \\
\text { Order }\end{array}$ & $\begin{array}{l}\text { No of } \\
\text { streams }\end{array}$ & $\begin{array}{l}\text { Bifurcation } \\
\text { Ratio }\end{array}$ & $\begin{array}{l}\text { Mean } \\
\text { Bifurcation } \\
\text { Ratio }\end{array}$ & $\begin{array}{l}\text { Total length of } \\
\text { streams }(\mathrm{km})\end{array}$ & $\begin{array}{l}\text { Mean length of the } \\
\text { streams(km) }\end{array}$ & $\begin{array}{l}\text { Length } \\
\text { Ratio }\end{array}$ \\
\hline 1 & 16752 & & 1.8721 & 592.89 & 0.04 & 0.9991 \\
2 & 8164 & 2.051935 & & 290.94 & & \\
3 & 2697 & 3.027067 & & 95.08 & & \\
4 & 5018 & 0.537465 & & 175.80 & & \\
Total & 32631 & 5.616468 & & 1154.70 & & \\
\hline
\end{tabular}

\subsubsection{Assessment of Tributaries}

\section{Order and Number:}

As the first step for the drainage assessment, have extracted the streams numbers and orders in a drainage basin. Historically, Horton (1945), first proposed the concept of stream ordering ( Horton,1945). Strahlar (1952, 1953, and 1957) modified and simplified his scheme of stream ordering (Strahler,1964). In this study, the Strahlar method has been adopted because of its simplicity. According to Strahlar (1952), each smallest stream or tributary is categorized as a first order stream and convergence of two ' 1 st order' tributaries give the 2 nd order stream. The junction of two 2 nd order streams gives the third order. The junction of two different orders gives the higher category number and so on.

Stream order is a significant factor which provides the suggestion regarding the form of the basin and runoff behavior. The drainage area and stream order of the Hab Watershed has been shown in Figure 3.

Quantitative evaluation shows that basin has fourth order streams and overall measurement lengthwise is 1,154.70 $\mathrm{km}$ and it means bifurcation ratio is 1.8721 . The stream order and length disparity depends primarily on lithological variations. The results reflected the heterogeneous character of basin. Basin has dendritic and semi-dendritic drainage pattern which shows that the Hab watershed has heterogeneous lithology and less structural influence. 

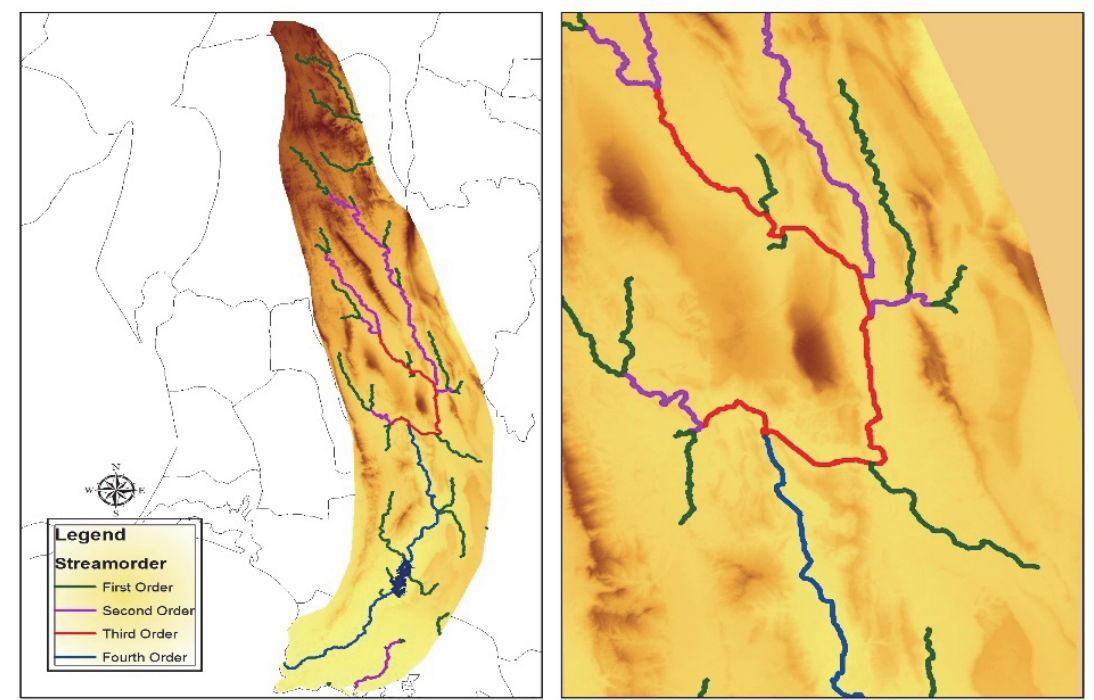

Figure 3. Stream network of Hab watershed

\subsubsection{Stream Characteristics}

Total measurement of streams have been done through DEM data with using Horton's law. according to that increase in stream order ultimately decreases the stream length. (Horton,1945). The same can be observed through Table No3.

The overflow from the some parts of the watershed is released through the tributaries, and, other factors being stable, the time essential for the water to run a given distance is directly proportional to the stream length.

Hydrological characteristics of a rock, like porosity and permeability, can be evaluated through total and mean stream length and stream ratio parameters. Geology and Physiography of the watershed area have strong effect on the relationship of these parameters. Total length of stream has been calculated $1,154.70 \mathrm{~km}$ and mean length 0.04 $\mathrm{km}$.

\subsubsection{Bifurcation Ratio}

It is a dimensionless number which demonstrates the ratio between the stream of one and next higher order stream (Table 2). It is an important measurement of drainage basin which reflects its risk for flooding. High bifurcation ratio predicts the greater probability of flooding.

Bifurcation ratio has been calculated for Hab watershed. The values vary from 2.05 to 0.5 whereas mean bifurcation ratio is 1.8721. Variation in bifurcation ratio predicts the less structural influences (Strahler,1957). Changes in its value be a sign of the change in the geometry of watershed and irregularities of lithology within the watershed.

\subsection{Areal Aspects of Hab Watershed}

Different areal aspects for Hab watershed were calculated from DEM through GIS. The prime morphometric parameters of the basin which affect the spatial distribution of different areal aspects have been calculated. Details are shown in Table 5.

\subsubsection{Elongation Ratio:}

It is the ratio of diameter of a circle of the same area of the basin to the maximum basin length (Schumm,1956), Table 3. According to Strahlar (1957), its value is between 0.6 and 1.0 which relates to diversity of climate and geology. Index of elongation ratio is instrumental to classify the slopes in a watershed.

Schuman (1956) defined a standard classification of the river basin elongation and later Strahlar interpreted the same in detail (Table 4). 
Table 4. Standard classification of the river basin elongation (Schuman, Saad, 2012)

\begin{tabular}{llll}
\hline Sequence & Standard & Classification & Stages of the Basin \\
\hline 1 & $<0.5-0.7$ & $\begin{array}{l}\text { more elongated and } \\
\text { elongated }\end{array}$ & Young \\
2 & $0.7-0.9$ & less elongated and oval & Maturity \\
3 & $0.9-0.10$ & circular & Aging \\
\hline
\end{tabular}

Elongation ratio in present study is computed by the method as proposed by Schumm (1956) and then verified by a mathematical equation which was presented by Saad-Falah (2013):

$$
R=A * B / C
$$

(equation)

Where, $\mathrm{R}=$ Elongation Ratio, $\mathrm{A}=$ Fixed factor (1.1282), $\mathrm{B}=$ Area of the Basin $/ \mathrm{km}^{2}, \mathrm{C}=$ Along the Basin $/ \mathrm{km}$.

The results show that the Hab Watershed has 0.35 elongation ratio which classifies the watershed in the more elongated basin category and predicts that this basin is in the young age category (Table 5).

Table 5. Areal Aspects of the Hab watershed

\begin{tabular}{lll}
\hline Parameters & Results & Description \\
\hline Basin area $\left(\mathrm{km}^{2}\right)$ & $14385.94 \mathrm{~km}^{2}$ & The basin area is very large \\
Basin length $(\mathrm{km})$ & 555.47 & Basin length is very high \\
Basin perimeter $(\mathrm{km})$ & 2439.25 & High basin perimeter \\
Elongation ratio & 0.35 & More elongated \\
Form factor & 0.046 & Elongated shape and flatter peak \\
Circularity ratio & 0.585 & $\begin{array}{l}\text { Strongly elongated and heterogeneous } \\
\text { Geological structure }\end{array}$ \\
Drainage requency & 2.26 & \\
Drainage density & 0.09 & more seepage, and less runoff \\
Drainage texture & 0.18 & coarse texture \\
\hline
\end{tabular}

\subsubsection{Circularity Ratio}

Water flows from its source to mouth where water supply rate to main stream is defined by the drainage basin shape. Circulatory ratio is the ratio of the basin area and the area of the circle that fitted in the same perimeter as the basin. Basin structure, its relief, slope and stream morphology directly affect the circulatory ratio.

The basin circularity index is 0.58 (Table 5), which specifies elongated shape of basin and consists of mixed geological material and structure. elongated and tapered basins of high bifurcation ratio forecasts about low release for a long time.

\subsubsection{Form Factor}

It is a dimensionless number. According to Horton, it is a ratio between the basin area and square of the basin length (Horton,1932).

It predicts about strength of stream flow in a watershed. Its smaller value shows the elongated character of basin. Its calculated value in recent study is 0.046 which predicts about elongated shape basin (Table 5). Smaller value and elongated shape of basin are evidence for flatter peak flow for short time period.

\subsubsection{Drainage Texture and Drainage Density}

Drainage density is a vital and useful index of basin individuality (Gregory and Walling,1968) as it has direct bearing on the magnitude of stream flow from drainage (Kirby and Chorley, 1967). It states as $\boldsymbol{Q} \boldsymbol{\alpha} \boldsymbol{D} \boldsymbol{d n}$. drainage density is average extent of stream calculated per unit area within a basin. 
Its value reflects the structural framework of formations with in a basin which is primarily controlled by inclined slope of the basin. It indicates the runoff travel time. The low drainage density in a basin shows more seepage, and less runoff. The calculated value of drainage density is 0.08 in the watershed. Drainage texture shows the relative space between drainage lines. It is controlled by rock material of underlying rocks and their capability of infiltration and area slope. According to Smith (Sylla, 2012) drainage texture categories are shown in Table (6).

Table 6. Drainage Texture Categories

\begin{tabular}{cc} 
Range & Texture category \\
\hline$<2$ & extremely coarse \\
$\mathbf{2}$ to 4 & coarse \\
$\mathbf{4}$ to 6 & moderate \\
$\mathbf{6}$ to 8 & fine \\
$>\mathbf{8}$ & extremely fine \\
\hline
\end{tabular}

Value of drainage texture for Hab watershed is 0.18 shows the coarse texture (Table 5). The low value of drainage density indicates that the region has a leaky and porous subsurface material with low relief.

\subsubsection{Drainage Frequency}

Drainage frequency of a basin is calculated by the total number of streams divided by the total area of a basin (Horton, 1932). Drainage density and stream frequency are interrelated values. For the Hab watershed, drainage frequency value is about 0.09 . Drainage frequency of Hab watershed is poor due to its poor stream network.

\subsubsection{Relief and relief Ratio}

Difference between the highest and the lowest point of the basin is called total relief (Schumm, 1963).

The relation between the total relief of a basin and the maximum distance end to end of the basin equivalent to the main drainage line is called Relief Ratio (Schumm, 1956).

Relief ratio specifies the gradient of a basin. Flow of surface water will increase on steep land and rate of percolation will reduce and risk of terrain degradation, erosion and floods will rise. Flat or less vertical land assists slow river flow which increases the recharge of ground water. Geologically, Hab River forms Hab valley which is a strike valley found on eastern limb of anticlinal fold of Pab range. geologically, Hab river valley is placed within the upper Nari formation of Oligocene age. Dip of the bed rock in Hab valley is south-east and about $5^{\circ}$ in the upper reaches but increases up to about $40^{\circ}$ in the terrain near Lang Lohari and additionally to downstream along the river.

Maximum height and mouth height of Hab basin can be seen in Fig 4(a) and relief map in Fig 4(b).

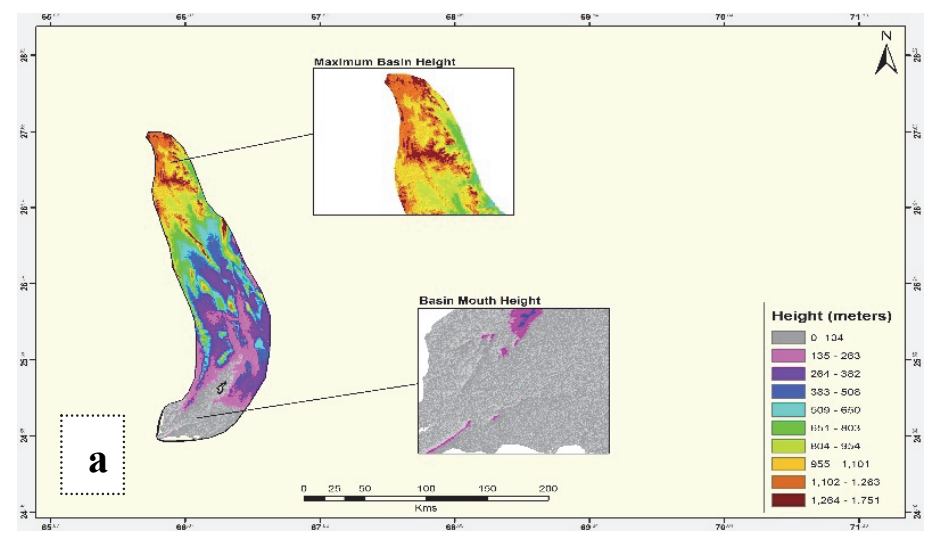




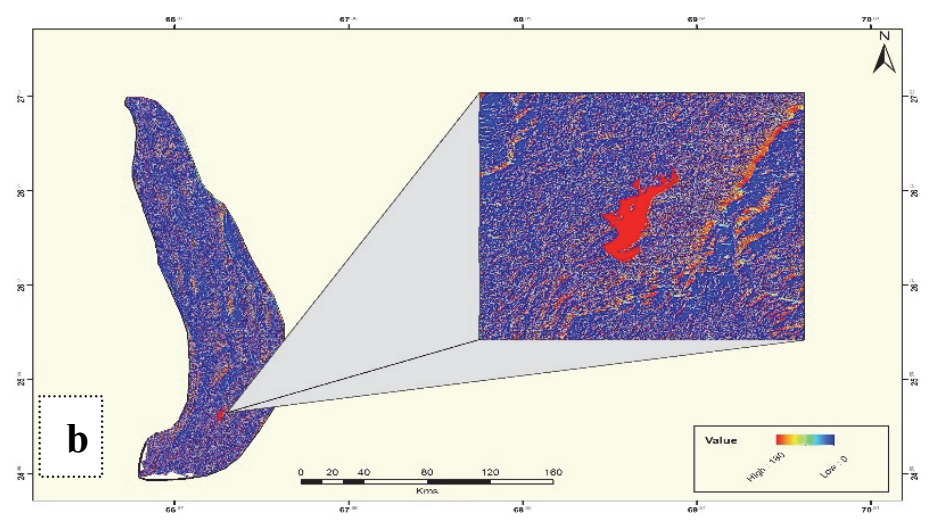

Figure 4. Relief map of study Area

\subsection{Slope Analysis}

The ratio among horizontal and vertical surface, of any area which is shown by the percentage and degree is called slope. Slope is a vital tool to monitor the relationship of infiltration rate and runoff intensity because infiltration rate in a basin is inversely proportional to slope. In this study, slope of the basin has been calculated in degrees and percents by using DEM data in GIS. Short length slope leads to steeply rising hydrograph limb and high discharges and steep slopes result in more sedimentation in the water body because of increased erosion.

The slope map (Figure 5) of the basin has been grouped into five categories, such as, $0^{\circ}-8^{\circ}$ (gentle), $9^{\circ}-17^{\circ}$ (moderate), $18^{\circ}-23^{\circ}$ (steep), $24^{\circ}-35^{\circ}$ (very steep) and above $36^{\circ}$ (very steep slope). It is observed that major area of Hab watershed comes under the category of sharp to extremely sharp and steep slope which specifies its hilly landscape.

lower portion of study area falls under the gentle and mild gradient category which is considered to be flat topography and is best suited for the ground water management through support for infiltration. On the other end, the mountainous topography of a steep slope has a negligible infiltration rate and higher surface and sub-surface runoff. Therefore, the slope is a most important parameter which directly influences the infiltration and runoff amount of any terrain condition and has significant control over development of aquifers.

The Hab River flows into the Arabian Sea to the west of Karachi and Hab Dam is about 30 miles north of Karachi. The storage area, the dam site and the area which is to be irrigated are

on a relatively low elevation below mean sea level (M.S.L) except for the eastern and western flanks of the upper part of the storage where hills and mountains with elevations between 600 feet to 2,000 feet and on some places it is high. The terrain is mostly hilly with characteristics even plateaus, "fairly high flanks" of considerable extent. The elevations of these plateaus generally remain below 300 feet. From the upper side of the basin, the Hab River flows through a narrow valley but as it stretches downstream, the river flows through broad and low terraces covered with relatively thin layers of alluvial deposits.

Ridges present in study area are the tributies of Kirthar ranges. These ridges are formed by hard bands of limestone. Morphology of these ridges can be grouped as hogback and cuesta ridges. 


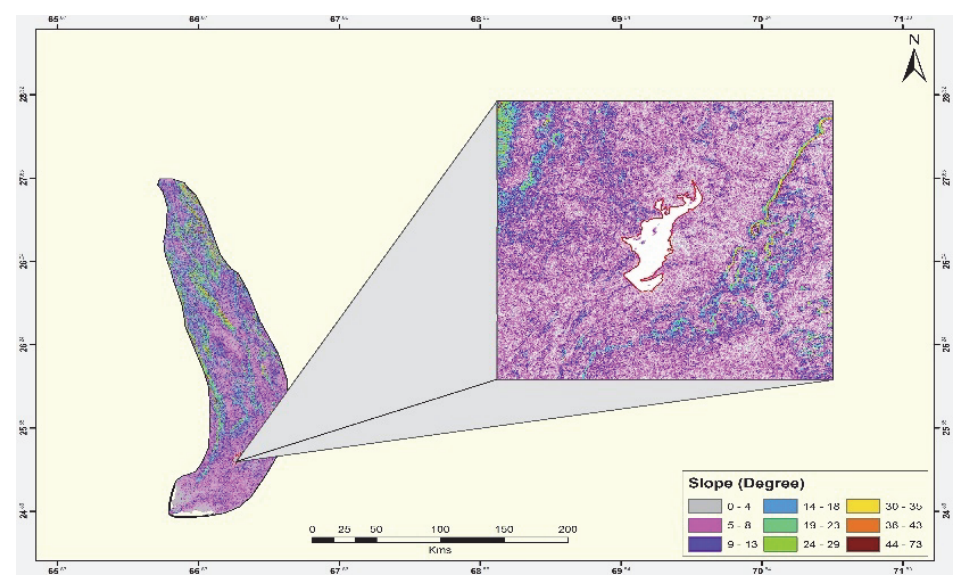

Figure 5. Slope map of the study area

\subsection{Aspects Map Generation}

Aspect map has been generated to understand the direction of mountain slope through DEM data. aspect values vary from 0 to 360.0 is True North where as 90 is the east facing slope (Figure 6).

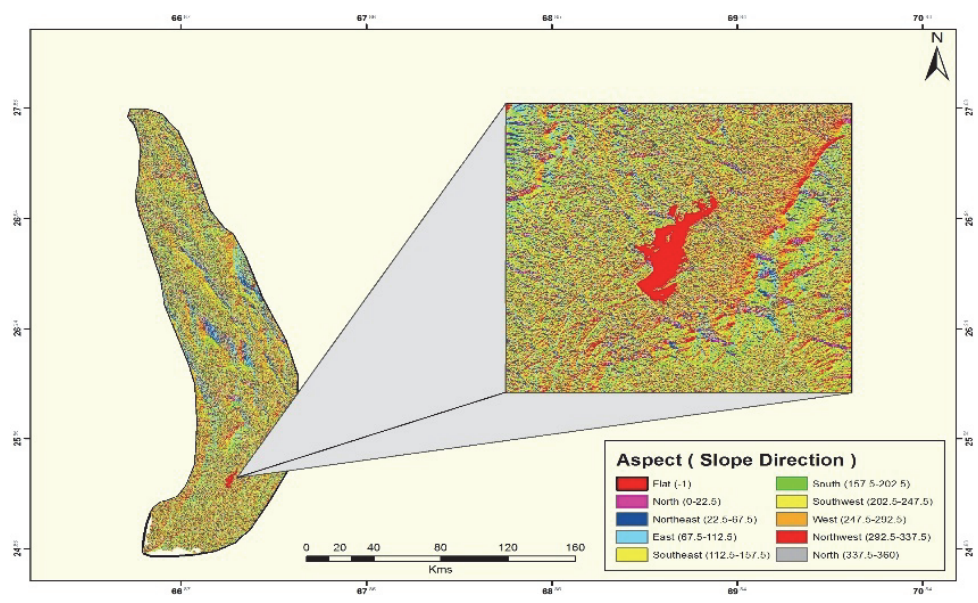

Figure 6. Aspect map of study area

Aspects map are useful to appreciate the impact of sun angle on the climatic conditions of study area. West facing slope indicates that the afternoon is the hottest time of a day indicating warmer conditions as compared to the east facing slope. The study area falls within the east and south west facing slope indicating low vegetation cover and lower moisture content as compare to west opposite gradient.

\subsection{Land Use and Land Cover Appraisal of Hab Watershed}

Land use and land cover (LULC) evaluation is very important mean for the examination of watershed area. Diverse man made activities, especially agricultural activities and urbanization have direct impact on it. (Singh et $a l, 2012$, Nian et al, 2014). Change in water demand for different activities like industrial and agricultural activities and domestic needs in a watershed can easily be understood by hydrological inferences through land use activities. Therefore, examination of land use and land cover change pattern has become a main parameter for Hydrological situation and natural resource management by many researchers (Sylla, 2012, Rawat et al, 2013, Nautiyal,1994, Wagner, 2013).

In this study, the assessment of Land use pattern has been extracted with classified Landsat 8 OLI data through supervised classification technique in Erdas imagine software. Finally, obtained categories mainly include Barren, Built-Up land, Water Bodies, Cultivated, Vegetation and Open Land (Figure 7). 


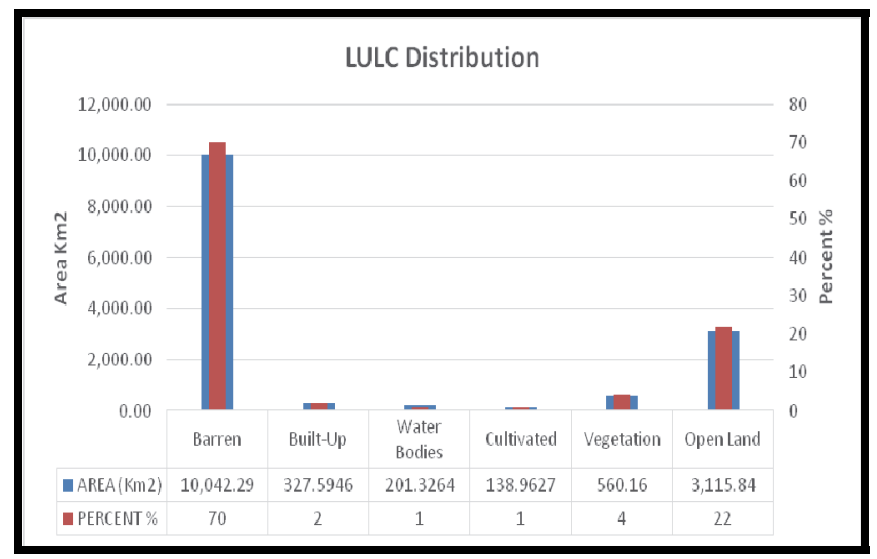

Figure 7. Land use and Land cover classes of study area

It is explored that most of the area of Hab Watershed is barren and open land and has mountainous relief. In the downstream side, close to Hab Dam, most of the area is cultivated and agricultural activities have been observed. Water bodies have been found with lower drainage density. These aspects indirectly affect the planning process and future water resource management (Table 7).

Table 7. Land use and Land cover classes of the Hab watershed

\begin{tabular}{lll}
\hline CLASS & AREA (Km2) & PERCENT \% \\
\hline Barren & $10,042.29$ & 70 \\
Built-Up & 327.5946 & 2 \\
Water Bodies & 201.3264 & 1 \\
Cultivated & 138.9627 & 1 \\
Vegetation & 560.16 & 4 \\
Open Land & $3,115.84$ & 22 \\
Total & $14,386.16$ & 100 \\
\hline
\end{tabular}

\subsection{Correlation of Morphometric and Hydrological Characteristics:}

For the analysis of hydrological characteristics and water budgeting of study area rainfall and annual inflow data has also been analyzed covering different time periods. Key aspects are listed in the ensuing paragraphs.

Precipitation directly contributes to hydrological basin in the form of snow and rain. The whole amount of rainfall does not convert in to flow or runoff. Rainfall data of Karachi and Lasbella has been analyzed being important stations of study area. (Figure 8 and 9). 


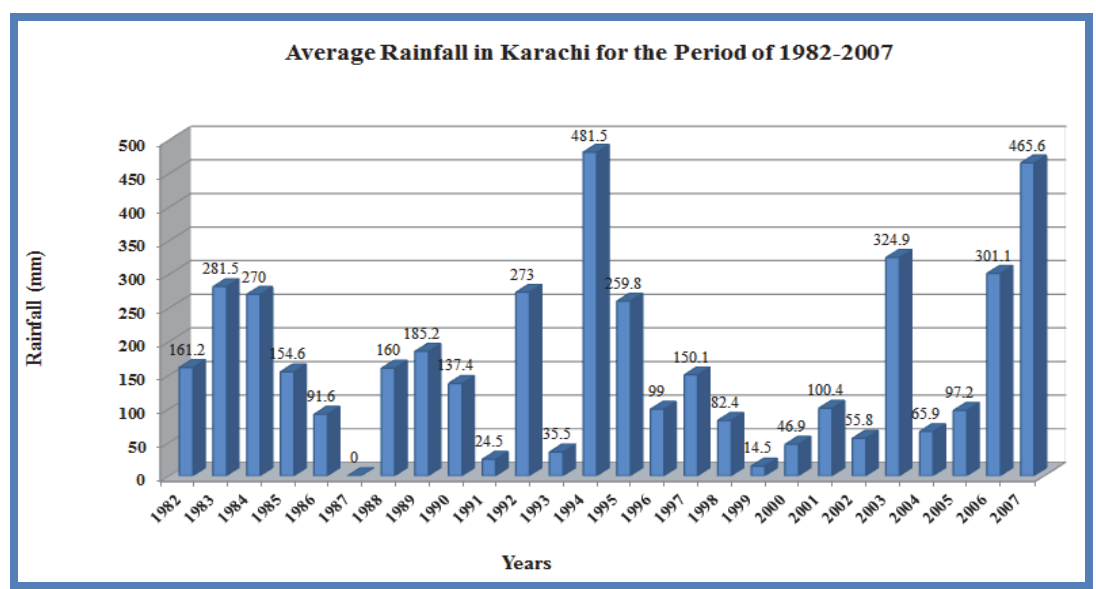

Figure 8. Annual Average Rainfall (mm) in Karachi

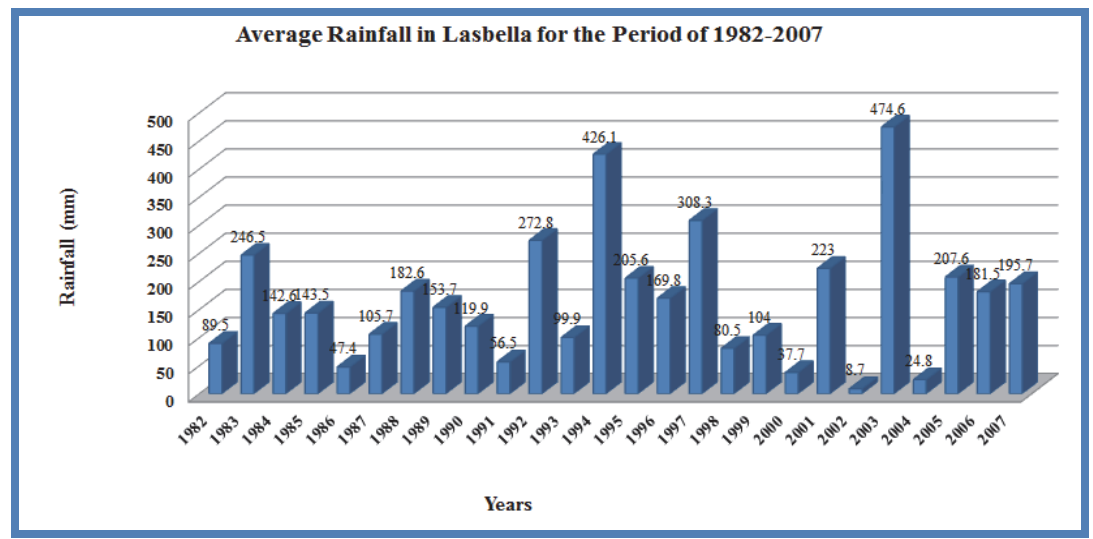

Figure 9. Annual average rainfall (mm) in Lasbella

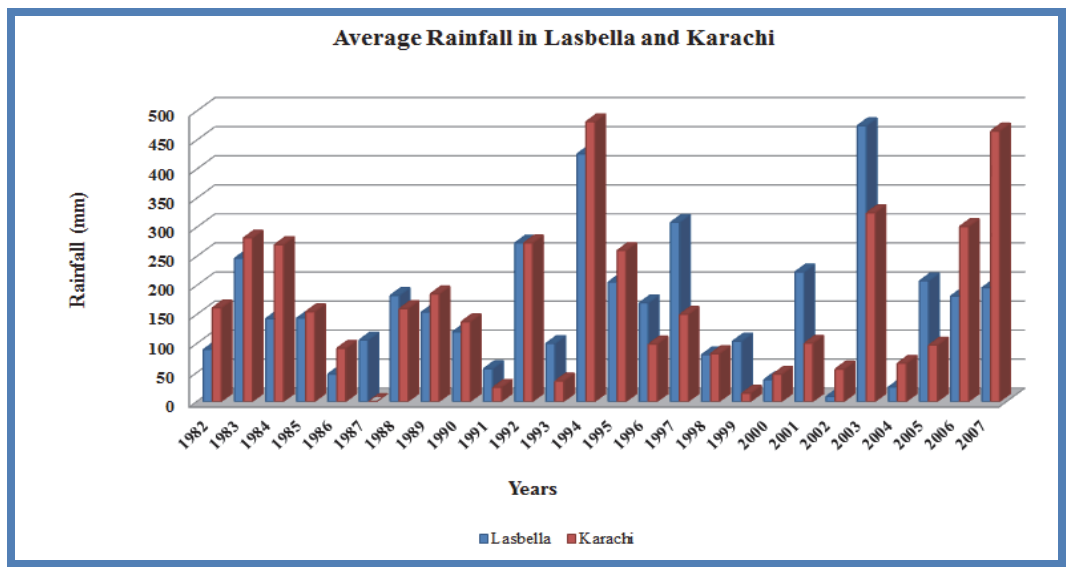

Figure 10. Comparison between annual average rainfall $(\mathrm{mm})$ in Lasbella and Karachi(WAPDA, 2010)

Figure 10 reflects that the precipitation history is inconsistent in the study area. precipitation pattern in Lasbella directly effects the water level of Hab reservoir. Annual rainfall pattern is also not regular in watershed. Pattern reflects varying trend in different years. Excessive rainfall during some of the years create flood situations and eventually considering non-availability of insufficient no of water reservoirs in the area along with limited capacity to store water leads to loss of water in sea (Fig 11). 


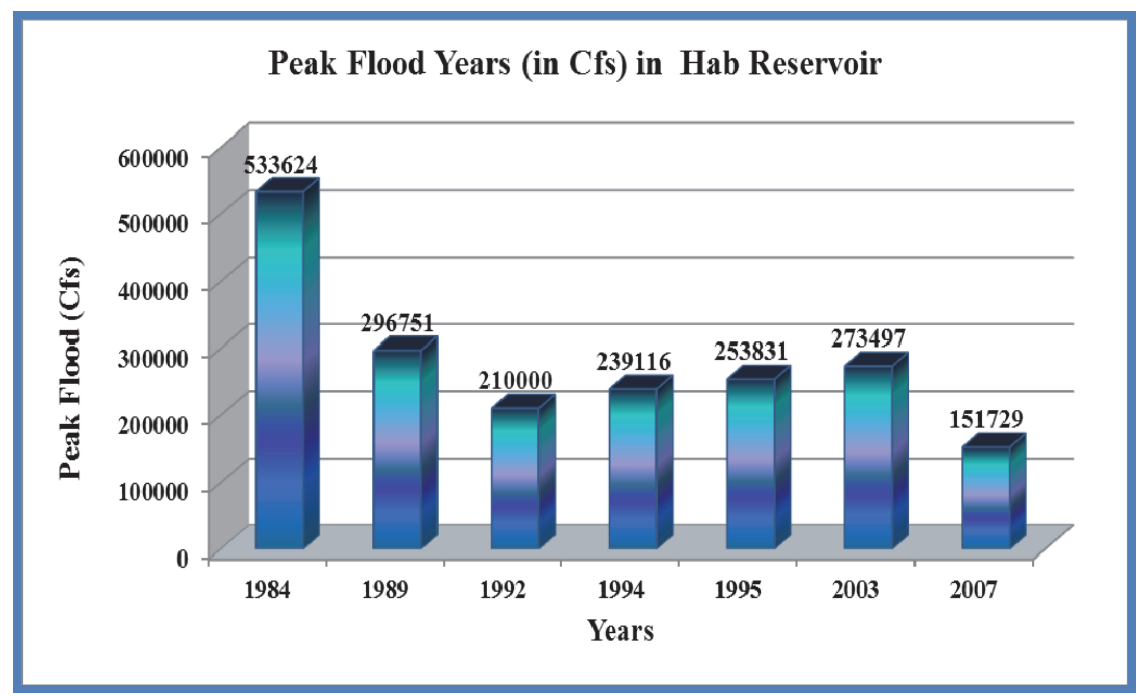

Figure 11. Peak flood years of Hab River (WAPDA)

On the other hand, during some of the years there are drought conditions owing to less precipitation. Such extreme flood and drought situations are likely to further worsen in forthcoming years owing to global warming effects. Generally, reservoir level minimum/maximum values of Hab Reservoir vary between 300 to 350 feet (Fig 12).

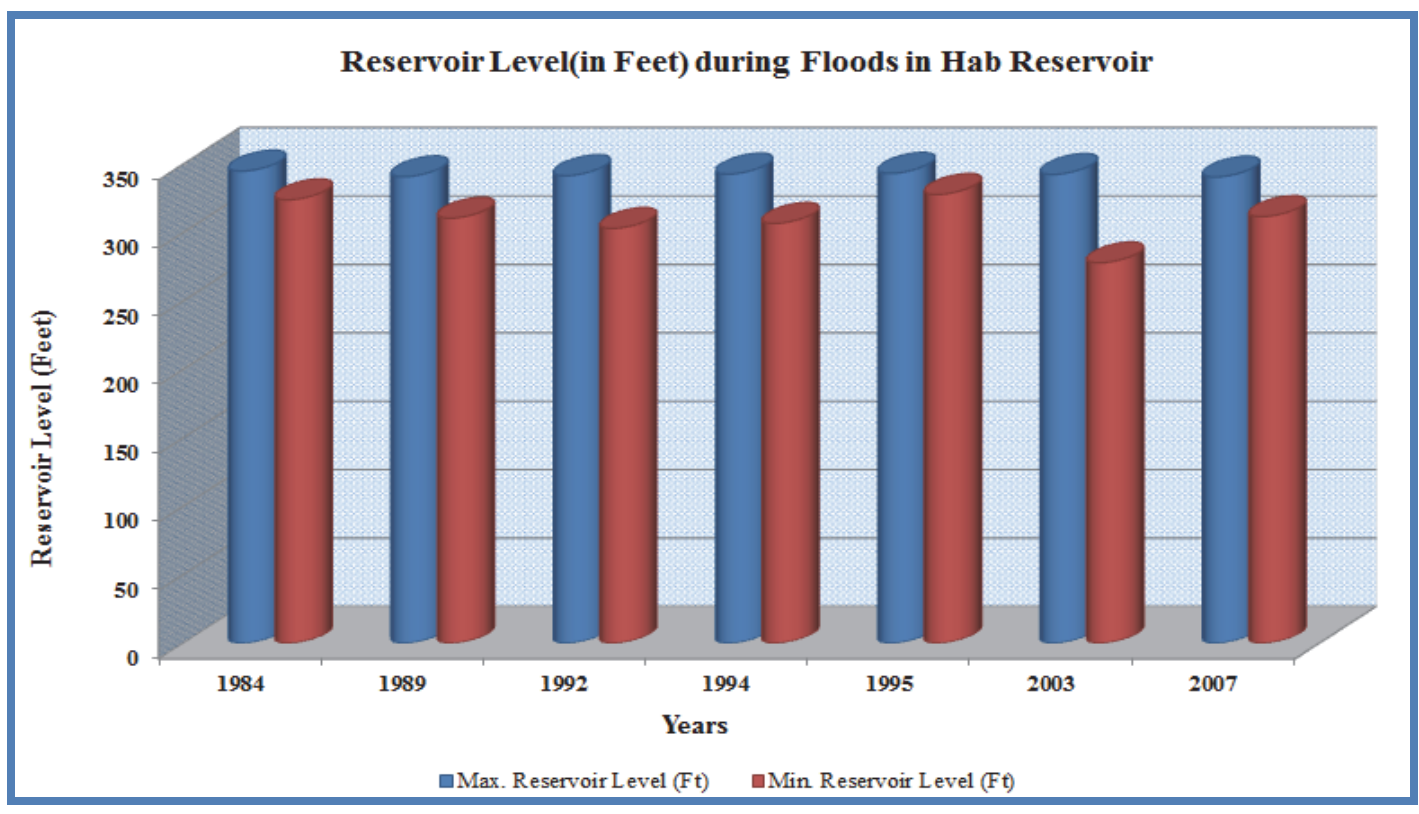

Figure 12. Maximum and minimum R.L of Hab reservoir for the period of 1984-2004 


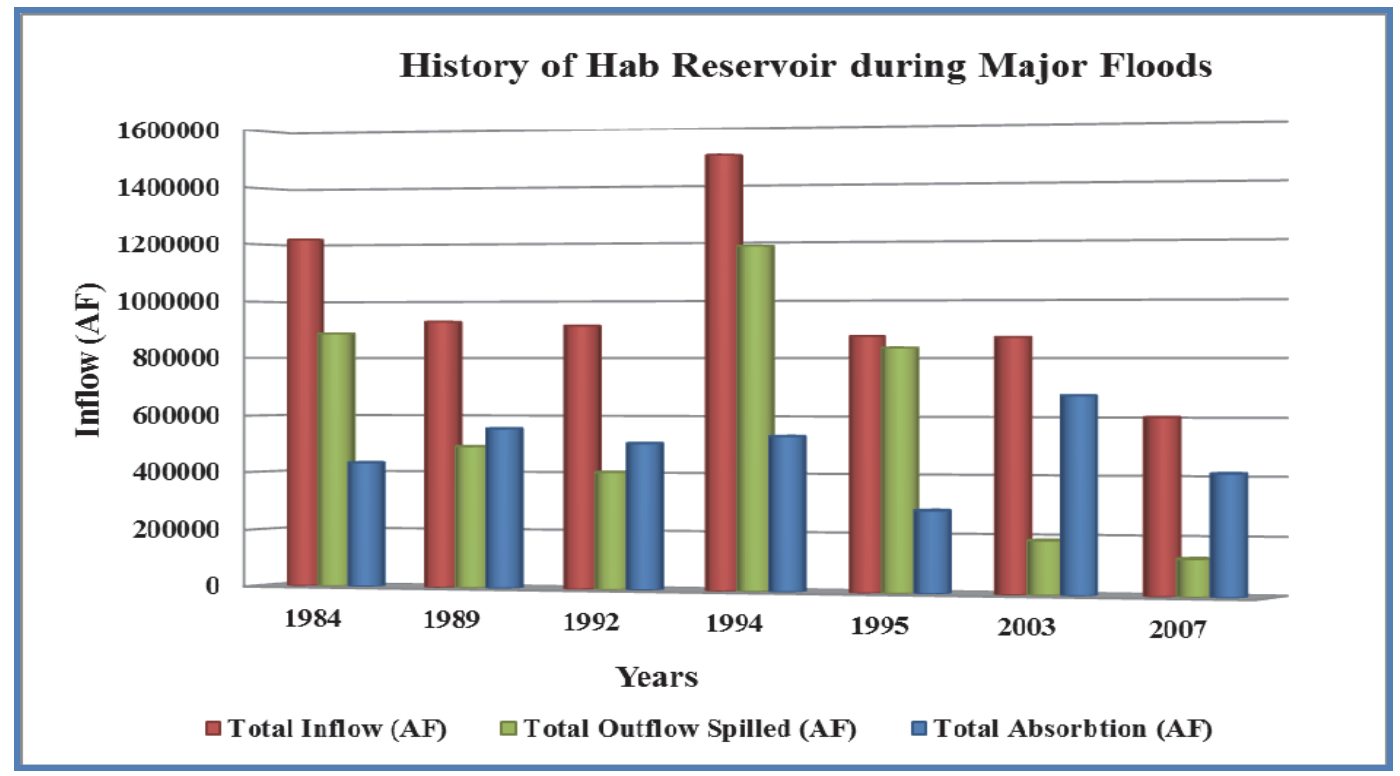

Figure 13. Comparison of inflow and outflow from Hab Reservoir for flood years of 1984-2007

Figure 13 shows comparison between inflow \& outflow values covering flood years. The graph demonstrates that there is a direct relation between inflow and outflow and morphological characteristics of watershed which limits its holding capacity. Because of this reason most of the water available during rains/flood season. This situation demands that there should be more water reservoirs in the Hab Watershed area with the capacity to store water for years to avoid wastage of water.

\section{Conclusions}

Morphometric analysis of Hab Watershed has shown high relief on upper side of watershed and moderate to low relief in lower area. The shape of watershed is elongated and it is a young age watershed. In the lower portion stream network is dendritic which indicates less structural influence and homogenous textural characteristics. The direction of flow of this river indicates that the general gradient of area is directed from NE to SW. Dendritic and trellis type of drainage pattern is common in overall study area.

Morphometric appraisal of the Hab River watershed based on SRTM DEM evaluation with RS and GIS technology has proved to be the most powerful and appropriate method for the appropriate understanding of hydrological constraints of its topographic features. It also indirectly influences the hydrological character of the watershed. The quantitative morphometric appraisal has a dominant utility for watershed demarcation and water and soil management for the sustainability of this valuable watershed. This study reveals that:

- There is huge diversity in availability of water resources of the Hab Watershed. Their availability is very intermittent both with respect to volume and time.

- There is massive difference in availability of water resources in different years.

- Storage capacity of Hab Watershed needs to be enhanced not only to capture the water available in monsoon season but to store water on annual bases as a long term solution.

\section{References}

Aravinda, P. T., \& Balakrishna. H. B. (2013). Morphometric Analysis of Vrishabhavathi Watershed using Remote Sensing and GIS. International Journal of Research in Engineering and Technology, 2(8).

Balakrishna, H. B. (2008). Spatial decision support system for watershed management using Remote Sensing and Geographic Information System, Ph.D. Thesis, UVCE, Department of Civil Engineering, Bangalore University.

Clarke, J. J. (1996). Morphometry from map, Essays in geomorphology, pp. 235-274. Elsevier Publishing Company, New York.

El Bastawesy, Garbs., M., \& White. K. H. (2013). Hydrology and geomorphology of the Upper White Nile 
Lakes and their relevance for water resources management in the Nile basin. Hydrological Processes, 27(1), 196-205. https://doi.org/10.1002/hyp.9216

Farr, T. G., \& Kobrick. M. (2000). Shuttle radar topography mission produces a wealth of data. Eos, Transactions, American Geophysical Union, 81, 583-585. https://doi.org/10.1029/EO081i048p00583

Gregory, K. J., \& Walling, D. E. (1968). The variation of drainage density within a catchment. International Association of Scientific Hydrology Bulletin, 13(2), 61-68. https://doi.org/10.1080/02626666809493583

Grohmann, C. H., Riccomini, C., \& Alves, F. M. (2007). SRTM-based morphotectonic analysis of the Pocos de Caldas alkaline Massif, southeastern Brazil. Computers and Geosciences, 33, 10-19. https://doi.org/10.1016/j.cageo.2006.05.002

Hinrichsen, D. (1998). Coastal waters of the world: Trends, threats and strategies, Washington, DC: Island Press.

Horton, R. E. (1945). Erosional development of streams and their drainage basins: Quantitative Morphology). Bulletin of the Geological Society of America, 56, 275-361. https://doi.org/10.1130/0016-7606(1945)56[275:EDOSAT]2.0.CO;2

Horton, R. E. (1932). Drainage basin characteristics, Transactions. American Geophysical Union, 13, $350-361$. https://doi.org/10.1029/TR013i001p00350

Islam, S. (2012). Pakistan in Red Zone as water resources decline. Published in The Express Tribune.

Javed, A., Khanday, M. Y., \& Ahmed, R. (2009). Prioritization of sub-watershed based on morphometric and land use analysis using remote sensing and GIS techniques. Journal of the Indian Society of Remote Sensing, 37, 261-274. https://doi.org/10.1007/s12524-009-0016-8

Jenson, S. K., \& Domingue, J. Q. (1988). Extracting topographic structures from digital elevation data for geographic information system analysis. Photogrammetric Engineering and Remote sensing, 54(11), 1593-1600.

Jha, M. K., Chowdhury. A., Chowdhry. V. M., \& Peiffer, S. (2007). Groundwater management and development by integrated RS and GIS: prospects and constraints. Water Resources Management, 21(2), 427-467. https://doi.org/10.1007/s11269-006-9024-4

JPL. (2017). Shuttle Radar Topography Mission (SRTM) Technical Fact Sheet JPL 400-713, Rev. 1, 7/98 (Jan 2017). Retrieved from http://www2.jpl.nasa.gov/srtm/factsheets.html (accessed January 24, 2017).

Kirkby, M. J., \& Chorley, R. J. (1967). Through flow, overland flow and erosion. International Association of Scientific Hydrology Bulletin, 12(3), 5-21. https://doi.org/10.1080/02626666709493533

Korkalainen, T. H. J., Lauren, A. M., \& Kokkonen, T. S. (2007). A GIS-based analysis of catchment properties within a drumlin field. Boreal Environment. Research, 1(2), 489-500.

Lefort, R. (1996). Down to the last drop. UNESCO Sources, 84(7).

Magesh, N. S., Jitheshlal, K. V., \& Chandrasekar, N. (2013). Geographical information system-based morphometric analysis of Bharathapuzha river basin, Kerala, India. Applied Water Sciences, 3, 467-477. https://doi.org/10.1007/s13201-013-0095-0

Mark, D. M. (1984). Automatic detection of drainage networks from digital elevation models. Cartographica, 21, 168-178. https://doi.org/10.3138/10LM-4435-6310-251R

Martz, L., \& Wand G. J. (1992). Numerical definition of drainage network and sub catchment areas from digital elevation models. Computers and Geosciences, $18(6)$, https://doi.org/10.1016/0098-3004(92)90007-E

Moore, I. D., Grayson, R. B., \& Ladson, A. R. (1991). Digital terrain modeling: A review of hydrological, geomorphological, and biological applications. Hydrological Processes, 5(1), 3-30. https://doi.org/10.1002/hyp.3360050103

Mubark, S. A., Aldarraji, S. A., Rushed, I., \& Alfadhili, F. (2013). Simplify Equation to Calculate Elongation River Basin Proposed by Schumm (1956). AL-USTATH 2.

Nautiyal, M. D. (1994). Morphometric analysis of drainage basin using aerial photographs: a case study of Khairkuli basin, District Dehradun, U.P. Journal of Indian Society of Remote Sensing, 22(4), $251-261$. https://doi.org/10.1007/BF03026526 
Nian, Y. Y., Zhou, J., Li, X., \& Hu X. (2014). The impact of land use change on water resource allocation in the middle reaches of the Heihe River Basin in northwestern China. Journal of Arid Land, 6, 273-286. https://doi.org/10.1007/s40333-013-0209-4

Panhalkar, S. S. (2014). Hydrological modeling using SWAT model and Geoinformatic techniques. Egyptian Journal of Remote Sensing and Space Science, 17, 197-207. https://doi.org/10.1016/j.ejrs.2014.03.001

Pramanik, M. K. (2016). Morphometric Characteristics and Water Resource Management of Tista River Basin Using Remote Sensing and GIS Techniques. Journal of Hydrogeologyand Hydrologic Engineering, 5(1). https://doi.org/10.4172/2325-9647.1000131

Rawat, J. S., Biswas, V., \& Kumar, M. (2013). Changes in land use/cover using geospatial techniques: A case study of Ramnagar town area, District Nainital, Uttarakhand, India. Egyptian Journal of Remote Sensing and Space Science, 16, 111-117. https://doi.org/10.1016/j.ejrs.2013.04.002

Richards, K. S. (1981). General problems in morphology. In A Gordie (Eds.), Geomorphological Techniques (pp. 26-30).

Sadaf, R. (2014). Watershed modeling of Hab River valley, Baluchistan Pakistan through RS and GIS Techniques. Unpublished Ph.D. Dissertation, Department of Geography, University of Karachi.

Sadaf, R., Kazmi, S. J. H., Younes, I., \& Khaleeq, S. (2017). Delineation and Assessment of Hab watershed, Balochistan, Pakistan through Geo-spatial Technology. International Journal of Economic and Environment Geology, 8, 28-34.

Sangita, M. S., \& Nagarajan, R. (2010). Morphometric analysis and prioritization of sub watersheds using GIS and Remote Sensing techniques: a case study of Odisha, India. International journal of Geomatics and geosciences, 1(3).

Schumm, S. A. (1956). Evolution of Drainage Systems and Slopes in Bad Lands at Perth, Amboy, New Jersey. Bulletin of the Geological Society of America, 67, 597-646. https://doi.org/10.1130/0016-7606(1956)67[597:EODSAS]2.0.CO;2

Schumm, S. A. (1963). Sinuosity of alluvial rivers in the great plains. Bulletin of the Geological Society of America, 74, 1089-1100. https://doi.org/10.1130/0016-7606(1963)74[1089:SOAROT]2.0.CO;2

Shakil, A. (2012). Geoinformatics for assessing the morphometric control on hydrological response at watershed scale in the Upper Indus Basin. Journal Earth System Sciences, 121(6), 659-686. https://doi.org/10.1007/s12040-012-0192-8

Singh, P., Thakur, J. K., Kumar, S., \& Singh, U. C. (2012). Assessment of land use/land cover using Geospatial Techniques in a semi-arid region f Madhya Pradesh, India. In Thakur, S., \& Prasad, G. (Eds.), Geospatial Techniques for Managing Environmental Resources. Springer and Capital Publication, Heidelberg, Germany. https://doi.org/10.1007/978-94-007-1858-6_10

Singh, P., Thakur, J., \& Singh, U. C. (2013). Morphometric analysis of Morar River Basin, Madhya Pradesh, India, using remote sensing and GIS techniques. Environment Earth Sciences, 68, 1967-1977. https://doi.org/10.1007/s12665-012-1884-8

Smith, K. G. (1950). Standards for grading texture of erosional topography. American Journal of Science, 248, 655-668. https://doi.org/10.2475/ajs.248.9.655

Strahler, A. N. (1964). Quantitative Geomorphology of Drainage Basin and Channel Networks. Handbook of Hydrology (edited by Ven Te Chow) Mc Graw Hill, Section, pp. 4-11.

Strahler, A. N. (1957). Quantitative analysis of watershed geomorphology. Transactions. American Geophysical Union, 38, 913-920. https://doi.org/10.1029/TR038i006p00913

Sylla, L., Xiong, D., Zhang, H. Y., \& Bangoura, S. T. (2012). A GIS technology and method to assess environmental problems from land use/cover changes: Conakry, Coyah, and Dubreka region case study. Egyptian Journal of Remote Sensing and Space Science, 15, 31-38. https://doi.org/10.1016/j.ejrs.2011.12.002

Tarboton, D. G. (1997). A new method for the determination of flow directions and contributing areas in grid digital elevation models. Water Resources Research, 33, 309-319. https://doi.org/10.1029/96WR03137

Tribe, A. (1991). Automated recognition of valley heads from digital elevation models. Earth surface processes and Landforms, 16(1), 33-49. https://doi.org/10.1002/esp.3290160105 
Vandana, M. (2013). Morphometric analysis and watershed prioritization. A case study of Kabini River Basin, Wayanad District, Kerala, India. Indian Journal of Geo Marine Sciences, 42(2), 211- 222.

Wagner, P. D., Kumar, S., \& Schneider, K. (2013). An assessment of land use change impacts on the water resources of the Mula and Mutha Rivers catchment upstream of Pune, India. Hydrology and Earth System Sciences, 17, 2233-2246. https://doi.org/10.5194/hess-17-2233-2013

WAPDA. (1984). Groundwater of Porali River Basin Baluchistan, Hydrogeology Project Quetta.

\section{Copyrights}

Copyright for this article is retained by the author(s), with first publication rights granted to the journal.

This is an open-access article distributed under the terms and conditions of the Creative Commons Attribution license (http://creativecommons.org/licenses/by/4.0/). 